\title{
Toxicity of Seven Pesticides belonging to Different Chemical Groups against the Glassy Clover Snail, Moncha Obstructa by using three Method of Application under Laboratory Conditions
}

\author{
Ahmed, A. Sallam';Abd El-Aleem, S.S. Desoky ${ }^{1}$; SherifAbouelkassem², Talat, \\ M. M. Abd El-Rahman ${ }^{2}$ \\ ${ }^{1}$ Plant protection Department, Faculty of Agriculture, Sohag University, Egypt \\ ${ }^{2}$ Plant protection Department, Faculty of Agric., Al-Azhar University, Branch Assiut, Egypt \\ abdelalem2011@yahoo.com
}

\begin{abstract}
The toxicity of seven pesticides belonging to different chemical groups asmetaldehyde, abamectin, methomyl, profenofos,copper hydroxyl, chlorfenapyr and imidaclopridby using three different methodsas DLL (Dipping lettuce leaves), BBMB (Baits of bran with methylene blue) and BBM (Baits of bran with molasses) against land snails, M. obstracta under laboratory conditions. Results presented that metaldehyde was the most toxic compound where $L C_{50}$ values by using methods of DLL, BBMB and BBM were 151, 52 and 60 ppm, respectively, while imidacloprid was the least toxic compound where $L_{50}$ values methods of DLL, BBMB and BBM were 36111, 33792 and 36789, respectively. These compounds could be arranged as following: metaldehyde > abamectin > methomyl > profenofos > copper hydroxyl > chlorfenapyr > imidacloprid.Moreover, the study presented that toxicity of any tested compound was varied according to the method of application and method of BBMB was the most effective following:DLL and BBMwith all tested pesticides except copper hydroxyl was method of DLL was the most effective following: BBMB and BBM.
\end{abstract}

Keywords: $D L L, B B M B, B B M$, land snails, Moncha obstructa.

\section{INTRODUCTION}

The terrestrial snails became an economic serious pest in Egypt. Land snails attackdifferent kinds of plants i.e cereal, vegetables, orchard trees and ornamental plants at thedifferent growth stages and reducing their yield (El-Okda, 1980). It causes serious economicdamage especially in horticulture and ornamental plants (Godan, 1983). In addition, the movement of snails causes an undesirable smell which prevents men and even animals from feeding on these contaminated plants (El-Okda, 1984; Kassab and Daoud, 1964; Sallam et al., 2009). The chemical control of snail populations through the application of molluscicides remained the most effective method, particularly over large areas (Miller et al., 1988; Heiba et al., 2002; Radwan $\boldsymbol{e t}$ al., 2008). Currently these snail species are controlled chemically by using certainpesticides with using many different methods and this is similar to the main aim of the present study forcontrolling M. obstracta under laboratory conditions.

\section{MATERIALS AND METHODS}

\subsection{Tested Pesticides}

seven pesticides belonging to different chemical groups asmetaldehyde (Gastrotox ${ }^{\circledR}$ E $5 \% \mathrm{G}$ ), abamectin (Cam-mek 1.8\% EC), methomyl(Lannate @ 90\% SP), profenofos (Seliton 72\% EC),copper hydroxyl (Zoom2007 25\% WP), chlorfenapyr (Challenger ® $36 \%$ SC) and imidacloprid (Imidor 35\% $\mathrm{SC})$.

\subsection{Tested Land Snails}

Land snail of M. obstracta werecollected from infested nurseries in experimental farm of the faculty of Agriculture Assuit university, field crops in Assuit Governorate next to El Azhar Carpark and field crops in El-Wasta in Assiut Governorate as described by Genena (2008). The obtained snails were transferred in plastic bags tothe laboratory, then kept in plastic containers filled with moist sandyloamy soil $1: 1$ by volume and fed on fresh leaves of lettuce (Lactucasativa L.) for 15 days to be laboratory acclimatized. Dead snails wereremoved and only healthysnailswere used in the following experiments. 


\subsection{Method of Application}

Dipping leaves method: These compounds were tested on land snail species M. obstracta using leaf dip method technique. Plastic cups (500 gm capacity) filled with moist sandy loamy soil as described above then covered with their plastic cover contained certain holes. Fresh lettuce leaves were washed carefully and dried placed on the plastic cups as a food for the tested land snails for several days before the experiment. For pesticides treatment, fresh lettuce leaves were dipped in different concentrations to each compound for 60 seconds then left for dryness.

Baits with methelyn blue:Pesticide baits were prepared according to the method suggested by Hanafy et al. (1998). Accordingly, concentration of the tested pesticides was dissolved in $100 \mathrm{ml}$ water, addition to the methylene blue $0.5 \%$ as attracted material. After that, each of the pesticide concentration was mixed with $100 \mathrm{gm}$ wheat bran then they are mixed well. Control treatment was prepared by using wheat bran, methylene blue $0.5 \%$ and $100 \mathrm{ml}$ water then they are mixed well without addition of pesticide concentration.

Baits with molasses (Honey sugar cane): Pesticide baits were prepared according to the method suggested by Ghamry et al. (1994). Accordingly, concentration of the tested pesticides was dissolved in $100 \mathrm{ml}$ water, addition to $5 \mathrm{ml}$ molasses as attractant material. After that, each of the pesticide concentration was mixed with $95 \mathrm{gm}$ wheat bran, then,they are mixed well. Control treatment was prepared by using wheat bran, molasses and $100 \mathrm{ml}$ water then they are mixed well without addition of pesticide concentration.

In previous three methods, four replicates were preparedfor each concentration and ten adult snails similar in shape and age were transferred to each plastic cups after adding the bait to it. The plastic cups were placed under the laboratory conditions at $20 \mathrm{C} \pm 2 \mathrm{C}$ and $60 \% \pm 5 \% \mathrm{RH}$. Tested snails were examined after $1,2,3$ days, where the dead individuals were counted and removed.Mortality percentages in each population of the snail species werecalculated and corrected according to the Abbott's formula (1925).

\subsection{Data Analysis}

Probit analysis was done to estimate $\mathrm{LC}_{50}$ and $\mathrm{LC}_{90}$ values andconfidence limits as well as slope value of LCP lines for the seven pesticides using SPSS V. 10 system software (SPSS Inc., 1999).

\section{RESULTS AND DISCUSSION}

\subsection{Toxicity of the tested pesticides against the glassy clover snail, Moncha obstructa after 72 hour of treatment by using three method under laboratory conditions.}

Toxicity of seven pesticides belonged to different chemical groups against land snails, M. obstracta under laboratory conditions. These pesticides were include metaldehyde (Gastrotox ${ }^{\circledR}$ E $5 \% \mathrm{G}$ ), abamectin (Cam-mek 1.8\% EC), methomyl (Lannate ${ }^{\circledR}$ 90\% SP), profenofos (Seliton72\% EC),copper hydroxyl (Zoom 2007 25\% WP), chlorfenapyr (Challenger ® $36 \%$ SC) and imidacloprid (Imidor 35\% $\mathrm{SC})$, by using three different methods.

Results presented in table (1) indicated that metaldehyde was the most toxic compound compared with the rest of tested compounds which exhibited low toxicity levels by using method of dipping lettuce leaves against land snails, $M$. obstracta. LC $_{50}$ values were 151, 260, 5743, 8906, 11414, 26968 and $36111 \mathrm{ppm}$ and $\mathrm{LC}_{90}$ values were 384, 924, 18651, 25738, 38239, 120820 and 124534ppm for metaldehyde, abamectin, methomyl, profenofos, copper hydroxyl, chlorfenapyr and imidacloprid, respectively.

Table1. Toxicity of the Tested Pesticides against the Glassy Clover Snail, Moncha Obstructa after 72 Hour of Treatment by using Method of Dipping Lettuce Leaves Under Laboratory Conditions.

\begin{tabular}{|c|c|c|c|c|c|}
\hline Pesticides & $\begin{array}{c}\mathrm{LC}_{50} \pm \mathrm{SE} \\
(\mathrm{ppm})\end{array}$ & $\begin{array}{c}95 \% \text { Fiducial } \\
\text { limits } \\
(\mathrm{LCL}-U C L)\end{array}$ & $\begin{array}{c}\text { LC } \\
(\mathrm{ppm} \pm \mathrm{SE}\end{array}$ & $\begin{array}{c}\text { 95\% Fiducial } \\
\text { limits } \\
(\text { LCL-UCL) }\end{array}$ & $\begin{array}{c}\text { Slope } \\
\pm \\
\text { SE }\end{array}$ \\
\hline $\begin{array}{c}\text { Metaldehyde } \\
5 \% \mathrm{G}\end{array}$ & $151 \pm 10$ & $95-217$ & $384 \pm 21$ & $256-1133$ & $3.17 \pm 0.11$ \\
\hline $\begin{array}{c}\text { Abamectin } \\
1.8 \mathrm{EC}\end{array}$ & $260 \pm 17$ & $148-482$ & $924 \pm 51$ & $501-7090$ & $2.34 \pm 0.09$ \\
\hline $\begin{array}{c}\text { Methomyl } \\
90 \% \text { SP }\end{array}$ & $5743 \pm 410$ & $3543-9545$ & $18651 \pm 950$ & $10720-35630$ & $2.51 \pm 0.14$ \\
\hline
\end{tabular}


Toxicity of Seven Pesticides belonging to Different Chemical Groups against the Glassy Clover Snail, Moncha Obstructa by using three Method of Application under Laboratory Conditions

\begin{tabular}{|c|c|c|c|c|c|}
\hline $\begin{array}{c}\text { Profenofos } \\
72 \% \text { EC }\end{array}$ & $8906 \pm 328$ & $5357-13422$ & $34647 \pm 725$ & $16159-58028$ & $0.79 \pm 0.01$ \\
\hline $\begin{array}{c}\text { Cooper hydroxide } \\
25 \% \text { WP }\end{array}$ & $11414 \pm 688$ & $7089-18664$ & $38239 \pm 988$ & $23300-905947$ & $2.46 \pm 0.10$ \\
\hline $\begin{array}{c}\text { Chlorfenapyr } \\
36 \% \text { SC }\end{array}$ & $26968 \pm 775$ & $16443-77746$ & $120820 \pm 6521$ & $50459-269936$ & $2.09 \pm 0.09$ \\
\hline $\begin{array}{c}\text { Imidacloprid } \\
35 \% \text { SC }\end{array}$ & $36111 \pm 820$ & $20908-54253$ & $124534 \pm 6760$ & $65621-289741$ & $2.64 \pm 0.08$ \\
\hline
\end{tabular}

Notes: $\boldsymbol{L} \boldsymbol{C}_{50}$ lethal concentration that kills $50 \%$ of the exposed snails. $\boldsymbol{L} \boldsymbol{C}_{\mathbf{9}}$ lethalconcentration that kills $90 \%$ of the exposed snalis.SE standard error (all values are mean of four replicates). LCL lower confidence limit.UCL upper confidence limit. Slope Regression Coeff.

As shown in Table (2) similar resultswere obtained to tested pesticides by using baits of bran with methylene blue 0.5 against land snails, M. obstracta. LC $_{50}$ values were 52, 170, 3154, 8897, 22450, 24812 and $33792 \mathrm{ppm}$ and $\mathrm{LC}_{90}$ values were 127, 491, 8342, 34647, 70210, 72377 and $76741 \mathrm{ppm}$ for metaldehyde, abamectin, methomyl, profenofos,copper hydroxyl, chlorfenapyr and imidacloprid, respectively.

Table2. Toxicity of the Tested Pesticides against the Glassy Clover Snail, Monchaobstructa after 72 Hour of Treatment by using Baits of Bran with Methylene Blue 0.5\% Under Laboratory Conditions

\begin{tabular}{|c|c|c|c|c|c|}
\hline Pesticides & $\begin{array}{c}\text { LC }_{50} \pm \text { SE } \\
(\mathrm{ppm})\end{array}$ & $\begin{array}{c}\text { 95\% Fiducial } \\
\text { limits } \\
(\text { LCL-UCL) }\end{array}$ & $\begin{array}{c}\text { LC }_{90} \pm \text { SE } \\
(\mathrm{ppm})\end{array}$ & $\begin{array}{c}\text { 95\% Fiducial } \\
\text { limits } \\
\text { (LCL-UCL) }\end{array}$ & Slope \pm SE \\
\hline $\begin{array}{c}\text { Metaldehyde } \\
5 \% \mathrm{G}\end{array}$ & $52 \pm 2$ & $33-74$ & $127 \pm 6$ & $85-436$ & $3.25 \pm 0.05$ \\
\hline $\begin{array}{c}\text { Abamectin } \\
1.8 \text { EC }\end{array}$ & $170 \pm 7$ & $112-281$ & $491 \pm 23$ & $293-1755$ & $2.76 \pm 0.04$ \\
\hline $\begin{array}{c}\text { Methomyl } \\
90 \% \text { SP }\end{array}$ & $3154 \pm 55$ & $2121-4843$ & $8342 \pm 345$ & $5277-29099$ & $0.81 \pm 0.02$ \\
\hline $\begin{array}{c}\text { Profenofos } \\
72 \% \text { EC }\end{array}$ & $8897 \pm 328$ & $5246-18131$ & $25738 \pm 792$ & $17368-73657$ & $2.16 \pm 0.04$ \\
\hline $\begin{array}{c}\text { Cooper hydroxide } \\
25 \% \text { WP }\end{array}$ & $22450 \pm 735$ & $12374-49640$ & $70210 \pm 3399$ & $51416-150706$ & $1.96 \pm 0.13$ \\
\hline $\begin{array}{c}\text { Chlorfenapyr } \\
36 \% \text { SC }\end{array}$ & $24812 \pm 761$ & $16143-39202$ & $72377 \pm 1131$ & $49875-160112$ & $2.41 \pm 0.08$ \\
\hline $\begin{array}{c}\text { Imidacloprid } \\
35 \% \text { SC }\end{array}$ & $33792 \pm 837$ & $23423-46529$ & $76741 \pm 1435$ & $49719-168973$ & $3.77 \pm 0.16$ \\
\hline
\end{tabular}

Notes: $\boldsymbol{L} \boldsymbol{C}_{50}$ lethal concentration that kills $50 \%$ of the exposed snails. $\mathbf{L} \boldsymbol{C}_{\mathbf{9 0}}$ lethalconcentration that kills $90 \%$ of the exposed snalis.SE standard error (all values are mean of four replicates). LCL lower confidence limit. UCL upper confidence limit.Slope RegressionCoeff.

As shown in Table (3) similar resultswere obtained to tested pesticides by using baits of bran with molasses against land snails, $M$. obstracta. LC $_{50}$ values were $60,271,14078,15690,23645,27562$ and $36789 \mathrm{ppm}$ and $\mathrm{LC}_{90}$ values were 182, 1193, 41836, 56116, 85375, 127864 and $151609 \mathrm{ppm}$ for metaldehyde, abamectin, methomyl, profenofos,copper hydroxyl, chlorfenapyr and imidacloprid, respectively.

Table3. Toxicity of the Tested Pesticides against the Glassy Clover Snail,Monchaobstructa after 72 Hour of Treatment by using Baits of Bran with Molasses under Laboratory Conditions.

\begin{tabular}{|c|c|c|c|c|c|}
\hline Pesticides & $\begin{array}{c}\mathrm{LC}_{50} \pm \mathrm{SE} \\
(\mathrm{ppm})\end{array}$ & $\begin{array}{c}95 \% \text { Fiducial } \\
\text { limits } \\
(\mathrm{LCL}-\mathrm{UCL})\end{array}$ & $\begin{array}{c}\mathrm{LC}_{90} \pm \mathrm{SE} \\
(\mathrm{ppm})\end{array}$ & $\begin{array}{c}\text { 95\% Fiducial } \\
\text { limits } \\
\text { (LCL-UCL) }\end{array}$ & $\begin{array}{c}\text { Slope } \pm \\
\text { SE }\end{array}$ \\
\hline $\begin{array}{c}\text { Metaldehyde } \\
5 \% \mathrm{G}\end{array}$ & $60 \pm 2$ & $37-97$ & $182 \pm 6$ & $108-367$ & $2.67 \pm 0.04$ \\
\hline $\begin{array}{c}\text { Abamectin } \\
1.8 \mathrm{EC}\end{array}$ & $271 \pm 9$ & $167-509$ & $1193 \pm 62$ & $600-2253$ & $1.99 \pm 0.03$ \\
\hline $\begin{array}{c}\text { Methomyl } \\
90 \% \text { SP }\end{array}$ & $14078 \pm 413$ & $9304-23960$ & $41836 \pm 1446$ & $24410-108394$ & $2.70 \pm 0.06$ \\
\hline $\begin{array}{c}\text { Profenofos } \\
72 \% \mathrm{EC}\end{array}$ & $15690 \pm 496$ & $9883-32090$ & $56116 \pm 2197$ & $28875-114064$ & $2.31 \pm 0.05$ \\
\hline
\end{tabular}


Ahmed, A. Sallam et al.

\begin{tabular}{|c|c|c|c|c|c|}
\hline $\begin{array}{c}\text { Cooper hydroxide } \\
25 \% \text { WP }\end{array}$ & $23645 \pm 657$ & $12823-40061$ & $85375 \pm 3878$ & $45425-182018$ & $2.10 \pm 0.04$ \\
\hline $\begin{array}{c}\text { Chlorfenapy } \\
\text { r 36\% SC }\end{array}$ & $27562 \pm 565$ & $16794-81035$ & $127864 \pm 3262$ & $51371-300106$ & $2.00 \pm 0.05$ \\
\hline $\begin{array}{c}\text { Imidacloprid } \\
35 \% \text { SC }\end{array}$ & $36789 \pm 1195$ & $17852 \pm 66313$ & $151609 \pm 8179$ & $78020-371984$ & $2.08 \pm 0.05$ \\
\hline
\end{tabular}

Notes: $\boldsymbol{L C}_{50}$ lethal concentration that kills $50 \%$ of the exposed snails. $\boldsymbol{L C}_{\mathbf{9 0}}$ lethalconcentration that kills $90 \%$ of the exposed snalis.SE standard error (all values are mean of four replicates). LCL lower confidence limit.UCL upper confidence limit.Slope RegressionCoeff.

When discussing the foregoing results, it is worthy to mention here that may be due to toxicity of metaldehyde increasingduring dry climatic conditions is similar to climate of Assuit Governorate, these results are agreement with (Dax1, (1970; Moens, 1970) They are applied during dry climatic conditions are usually more successful than the degree of control achieved during damp, high humidity conditions, at which time snails are likely to be more active. (Henderson, 1970; Henderson and Triebskorn, 2002) The principal toxic effect of metaldehyde is through stimulation of the mucous gland which cause excessive sliming, leading to death by dehydration. Also, Abd El-Wakeil (2005)studied that the metaldehyde can affect mollusks either by contact, with absorption through the skin, or through the gut when eaten. The main effect is that of an irritant, causing the molluscs to produce masses of mucus, leading to dehydration and sometimes death. Loss of mucus also means that the animals can no longer move around, so that death and dying animals are found close to the baiting site. Molluscs that have been poisoned by methiocarb can however, move around for a while, but then swell up with fluid and become immobile dying shortly afterwards. In dry conditions this swelling can be reduced, and some animals may recover, although generally recovery rates are lower than with metaldehyde. These results are agreement with Ghamry et al. (1993) found that metaldehyde, methiocarb, thiocarb, cyanophos and monocrotophos were tested by using baits against two landsnails, M. cartusiana and E. vermiculata. They found thatmortality after 14 days were 93 , 87,70, 45 and $36 \%$ for $M$. cartusiana and $85,82,63,39$ and $28 \%$ for E. vermiculata,respectively. Also, Abd El-Aal andHamed (2010)found that metaldehyde, profenofos were the most toxic to $E$. vermiculataand $M$. cartusiana with toxicity index of $88.6,97.3$ and $100.0,100.0$,respectively. Also, El Gohary and Genena (2011) studied the effect three molluscicide, Gastrotox, Mlotov, and Mesurol in tissues of the two land snails, Monachacantiana and Eobania vermiculata.They found that the three molluscicides were affected in the activities of five vital enzymes, total lipid and total protein when applied against the tested land snails.Also,El Gohary and Genena (2011) studied the effect three molluscicide, Gastrotox, Mlotov, and Mesurol in tissues of the two land snails, Monachacantiana and Eobania vermiculata.They found that the three molluscicides were affected in the activities of five vital enzymes, total lipid and total protein when applied against the tested land snails. While, El-Okda et al. (1989) Study of toxicity methomyl, aldicarb ,oxyamyl, methiocarb, du-pont-1642 and metaldehyde by using baits against Helix sp., E vermiculata, T. pisana, Rumina sp., Cochlicella sp., Helicella sp. Limax sp. andOxychilus sp.,they found that aldicarb, methomyl, oxamyl and du-pont-1642 showed the highest toxicity, on the other hand methiocarb and metaldehyde wereless toxicity. Ghamryet al. (1994) evaluated fourteen insecticides against tow land snails; $M$. contiana andE. vermiculata. Results from bait testes revealed that, methomyl, dithiocarb, carbaryl,chlorpyrifos and dimethoate were effective for killing snails after 12 days under laboratoryconditions. On the other hand, the same trend was observed with those insecticides underfield conditions. El-Okda et al. (1989) evaluated the efficacy of the formulated local $0.5 \%$, aldicarb, oxamyl ,methiocarb, Lannat and metaldhyde in controlling the land molluscs; H. aspersa, Eobania sp., Theba sp., Rumina sp. and oxychilus sp. The results indicated that, aldicarb, oxamyl andLannat gave the highest toxicity against the most snails and slugs species, while methiocarband metaldehyde were less toxic.

\subsection{Comparison of three Methods Treatment to Seven Pesticides after 72 Hour from Treatment against the Glassy Clover Snail, Moncha Obstructa under Laboratory Conditions}

Three different methods as DLL (Dipping lettuce leaves), BBMB (Baits of bran with methylene blue) and BBM (Baits of bran with molasses) were used to evaluation seven pesticides as metaldehyde, abamectin, methomyl, profenofos, copper hydroxyl, chlorfenapyr and imidacloprid, against land snails, M. obstractaunder laboratory conditions. Results presented in fig. 10\&11 indicated that toxicity of any tested compound was varied according to the method of application.Notes that method of 
Toxicity of Seven Pesticides belonging to Different Chemical Groups against the Glassy Clover Snail, Moncha Obstructa by using three Method of Application under Laboratory Conditions

BBMB was the mosteffective with metaldehyde, following: BBM and DLL. LC $_{50}$ values were 52, 60 and $151 \mathrm{ppm}$ and $\mathrm{LC}_{90}$ values were 127, 182 and $384 \mathrm{ppm}$, respectively. Also, Notes that method of BBMB was the mosteffective with abamectin, following: DLL and BBM. LC $_{50}$ values were 170,260 and $271 \mathrm{ppm}$ and $\mathrm{LC}_{90}$ values were 491, 924 and $1193 \mathrm{ppm}$, respectively. Also, Notes thatmethod of BBMB was the mosteffective with methomyl following: DLL and BBM. LC 50 values were 3154, 5743 and $14078 \mathrm{ppm}$ and $\mathrm{LC}_{90}$ values were 8342, 18651, and $41836 \mathrm{ppm}$, respectively. Also, Notes thatmethod of BBMB was the mosteffective with profenofos following: DLL and BBM. LC 50 values were 8897,8906 and $15690 \mathrm{ppm}$ and $\mathrm{LC}_{90}$ values were 25738,34647 , and $56116 \mathrm{ppm}$, respectively. While, notes that method of DLL was the mosteffective with copper hydroxyl, following: BBMB and BBM. $\mathrm{LC}_{50}$ values were 11414, 22450 and $23645 \mathrm{ppm}$ and $\mathrm{LC}_{90}$ values were 38239,70210 and 85375 ppm,respectively. Also,method of BBMB was the mosteffective with chlorfenapyr following: DLL and BBM. $\mathrm{LC}_{50}$ values were 24812, 26968 and $27562 \mathrm{ppm}$ and $\mathrm{LC}_{90}$ values were 72377, 120820, and $127864 \mathrm{ppm}$, respectively. Also, method of BBMB was the mosteffective with imidacloprid following: DLL and BBM. $\mathrm{LC}_{50}$ values were 33792, 36111 and $36789 \mathrm{ppm}$ and $\mathrm{LC}_{90}$ values were 76741, 124534, and 151609 ppm, respectively.

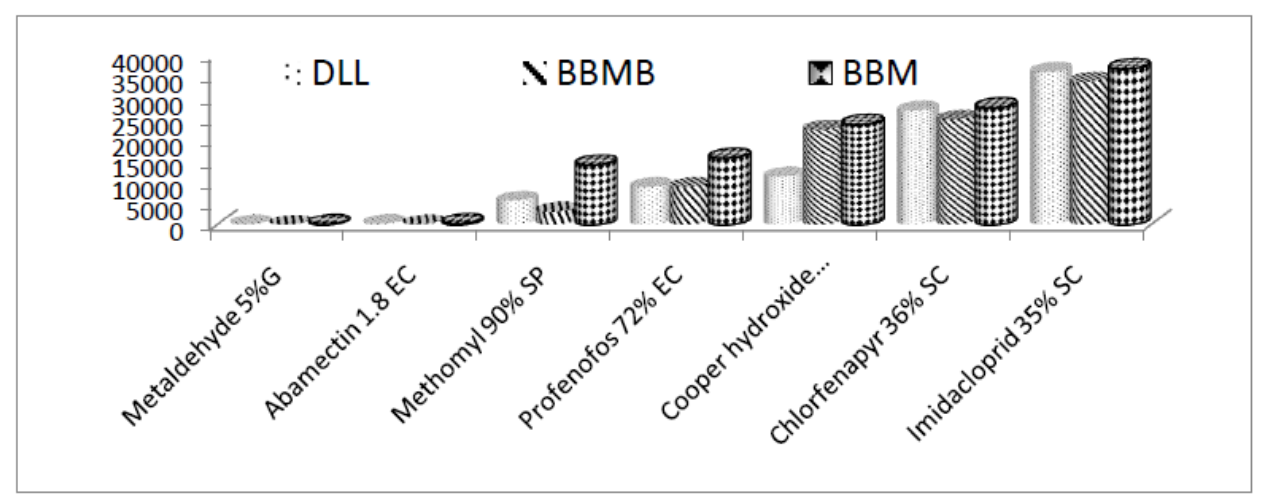

Fig1. Comparison of three Methods Treatment by using $L C_{50}$ to Seven Pesticides after 72 Hour from Treatment against the Glassy Clover Snail, Moncha Obstructa under Laboratory Conditions

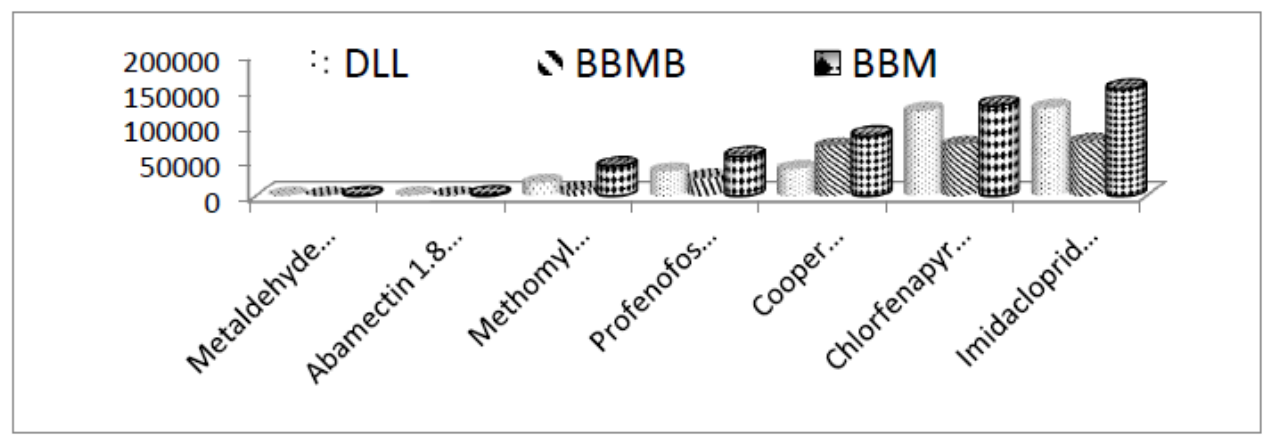

Fig2. Comparison of three Methods Treatment by using $L C_{90}$ to Seven Pesticides after 72 Hour from Treatment against the Glassy Clover Snail, Moncha Obstructa under Laboratoryconditions

Notes: DLL dipping lettuce leaves. BBMB baits of bran with methylene blue. BBM baits of bran with molasses.

When discussing the foregoing results, it is worthy to mention here that,method of BBMB was the mosteffective with metaldehyde, abamectin, methomyl, profenofos, chlorfenapyr and imidacloprid this may be due to blue color as attractive material for land snails. While,method of dipping lettuce leaves was the mosteffective with copper hydroxylthismay be due to that the color of baits converted to the green color because of the color of cooper hydroxide 25\% WP pesticide, in this case this may be due to that unattractiveness the snails to baits so method of dipping lettuce leaves was more effective than the baits. These results agreed with Ismail (2009)studied effect of three colors i.e. blue, green and red on attractiveness of Eobania vermiculata snails were tested in citrus orchard. Results revealed that blue colour was the most preferable, while red color was the lowest one. The effect of three carrier materials (fine wheat bran, boiling rice and dry crushed bread) on the efficiency of methomyl were studied against Monacha cartusianasnail. Boiling rice proved to be the most effective while carried material dry crushed bread was the lowest one. Two types of attractive materials (sugar can syrup and Birell syrup) were evaluated with the three previous carrier materials alone. Obtained 
results show that Birell syrup (Barley syrup) was more attractive than sugar cane syrup. Finally he recommended that adding blue colour to the poisonous baits increase its attractiveness and Birell syrup increase the efficiency of methomyl when applied as poisonous baits against the two land snails, Monacha cartusianaand Eobania vermiculataunder field conditions. Gabr et al. (2006) studied the effectiveness of certain pesticides namely, i.e. methomyl (Lannate); paraquate (Garamoxone); oxyfluorfen (Goal); Glyphosate (Lansar) and pendimethalin (Stomp) against adult stage of three species of land snails ( $H$. vestalis, $M$. contiana and $E$. vermiculata) under laboratory conditions using three methods for testing, i.e. direct spray, dipping and poisonous bait technique. He found that toxicity of any tested compound was varied according to the method of application.

\section{REFERENCES}

Abbott, W. W. (1925). A method of computing the effectiveness of an insecticide.J. Econ. Entomol., 18: 265-267.

Abd El-Aal, E. M. and Hamed, S. A.(2010).Controlling aspects against terrestrial snails Eobania vermiculata and Monacha cartusiana underlaboratory conditions. J. Agric. Res. Kafer El-Sheikh Univ., 36(4).

Abd El-Wakeil, K. F. (2005). Ecotoxicolgical studies on terrestrial isopods (Crustacea) in Assiut, Egypt. Ph. D. Thesis, Assiut Univ. Egypt, 271pp.

Daoud, M.I.A. (2004). Ecological and morphological studies on some terrestrial snails in Dakahlia Governorate. M.Sc. Thesis, Fac. Agric., Al-Azhar Univ., 170 pp.

Daxl, R. (1970). Der Einflub von Temperature and relative Luftfeuchte die MolluskizideWirkung die Metaldehyde. Isolan and Ioxynil auf Limax flavus und dessen Eier.Zeitschrift Angewandte Entomologie 67: 57-87.

El-Gohary, L.R. and Genena, M.A.(2011). Biochemical effect of three molluscicide baits against the two land snails Monacha cantiana and Eobania vermiculata (Gastropoda: Helicidae).Int.J.Agric.Res Vol. 6 Issue 9, p682.

El-Okda, M. K. (1980). Land snailseconomic importance on vegetable cropsat Alexandria and neighboring regions J .Agric. Res. Rev., 58 (1): 79-86.

El-Okda, M.K. (1984).Land mollusca infestation \& chemical control in El-IsmaeliaGovernorate. Agric. Res. Review, Egypt 62: 87-92.

El-Okda, M.K.; Mokta, M.K. and Hanafei, A.H. (1989). Preliminaryobservation on land Mollusca infesting fencing plants. Alex. Sci .Exch., 10 (2): 387-369.

Gabr, W. M.; Youssef, A. S. and Khidr, F. K. (2006). Molluscicidal effect of certain compoundagainst two land snail species, Monacha obstructa and Eobania vermiculata underlaboratory and field conditions. Egyptian J. Agric. Res., 4: 43-50.

Genena, M.A.M. (2008). Advanced studies on chemical and Biorational control of certain terrestrial gastropods.Ph.D.Thesis, Fac.Agric. Zool., Mansoura Univ. 113pp.

Ghamry, E.M.; El- Deeb, H.I. and Kokab, Y.A. (1993).Ecological and morphological studies on certain land snail at Sharkia Governorate. Egypt. J. Appl. Sci., 8 (11): 213-255.

Ghamry, E.M.; Kokab, Y.A. and Wilson, B.A. (1994). Screening test of someinsecticides against two lands snails Monacha cantiana and Eobania vermiculata in Sharkia Governorat e. Zagazig J. Agric .Res., 21 (5): 1539-1545.

Godan, D. (1983).Pest slugs and snails, Biology and Control. Springer Verlag, Berlin. 424 pp.

Hanafy, A.H.A.; Youssef, H.M.and El- Shahat, M.S. (1998). Preparation of methomyl baits and efficacy against certain land Mollusca in different vegetation. Adv. Agric. Res., 3 (3): 435-441.

Heiba, F.N.; Al-Sharkawy, M. I. and Al-Betal, A.A.(2002).Effect of the insecticide, lannate, on the land snails, Eobania vermiculata andMonacha cantiana, under laboratory conditions. J. biological Sci;2 (1): 8- 13.

Henderson, H. and Triebskorn, R. (2002).Chemical control of Terrestrial gastropods.CABInternational, Molluscs as crop pests Barker, G.M. (ed.), 31 pages.

Henderson, I.F. (1970). The Fumigant effect of metaldehyde on slugs. Annals Applied ofBiology 56: 507-510.

Ismail, S. A. A. (2009). Effect of bait colour, carrier and attractive materials on the efficiency of methomyl against two land snails species under field conditions. Al-Azhar J. Agric.Sci. Sector Res.,Vol.6: pp 245-254. 
Toxicity of Seven Pesticides belonging to Different Chemical Groups against the Glassy Clover Snail, Moncha Obstructa by using three Method of Application under Laboratory Conditions

Kassab, A. and Daoud, H. (1964).Notes on the biology \& control of land snail of economicimportance in the U.A.R. J. Agric. Res., Review, Cairo, 42: 66-98.

Miller, E.; Swails, S.; Swails, D.; Oslon, F. and Stalen, R. T. (1988). White garden snail Theba pisana efficacy of selected bait and spray able molluscicides. J. Agric. Entomol; 5 (3): 189 -197.

Moens, R. (1970). Techniques chimiques de destruction de gitesa limneesdans les prairies .Colloque information Scient., L" Assainissement des Prairies.par les Triatements molluscicides" Gemblouxcentre de Recherches agronomiques de l'Etat, 232-55,Gembloux.

Radwan, M.A.; Essawy, N.E.; Abdelmeguied, N.E.; Hamed, A.E. and Ahmed,A.E. (2008). Biochemical and histochemical studies on the digestive gland of Eobania vermiculata snails treated with carbamate pesticides. Pesticide biochemistry and Physiology, 90 :154-167.

Sallam A.A.A.; S.A. El-Massry and I.N. Nasr (2009). Chemical analysis of mucus from certain land snails under Egyptian conditions. Archives of Phytopathology and Plant Protection 42: 874-881. 